Wacław Cockiewicz

Uniwersytet Jagielloński, Kraków

wcockiewicz@interia.pl

\title{
JAK UPORZĄDKOWAĆ TERMINOLOGICZNY CHAOS W GLOTTODYDAKTYCE I PO CO?
}

Słowa klucze: glottodydaktyka, terminologia, język ojczysty, język rodzimy, język obcy, język pierwszy/ drugi..., bilingwizm/multilingwizm, poliglotyzm

Keywords: language pedagogy, terminology, mother tongue, native language, foreign language, L1/L2, bilingualism/multilingualism, polyglotism

Od wieków, a może i od zawsze, ścierają się w naukach, zwłaszcza humanistycznych, dwie tendencje: pierwsza, nazwijmy ją pozytywistyczną, koncentruje się na szczególe, empirii, dedukcji i analizie, dbając w ten sposób o siłę dowodową formułowanych tez, druga natomiast - romantyczna, modernistyczna, postmodernistyczna (mniejsza zresztą o nazwę) specjalizuje się w tworzeniu efektownych syntez i modeli, odrzucając żmudne obserwacje szczegółów i mało znaczących (w przekonaniu jej przedstawicieli) różnic. Obie są cenne i przyczyniają się do postępu nauk, zwłaszcza humanistycznych, ale każda z nich czemu innemu służy.

We współczesnym językoznawstwie poczesne miejsce zdobywa sobie kierunek wywodzący się ze środowiska amerykańskich psychologów zwany lingwistyką kognitywną, względnie gramatyką kognitywną, który jest, by posłużyć się jednym z jego własnych fundamentalnych pojęć, prototypowym reprezentantem drugiej z tych tendencji. Proponowany przez niego model języka odznacza się przede wszystkim tym, że koncentruje się na podobieństwach, pomijając różnice, które tak ważną rolę odgrywają w językoznawstwie strukturalnym. Dlatego kategorie wyróżniane w tym modelu koncentrują się wokół 
prototypu, łącząc się ze sobą swoimi peryferiami, co skutkuje brakiem ostrych granic pomiędzy nimi. Takie ujęcie odzwierciedla, zdaniem kognitywistów, z jednej strony procesy poznawcze leżące u podstaw języka, $\mathrm{z}$ drugiej zaś jego percepcję. Ta efektowna teza trafia do przekonania, choć brak na nią dowodu. Bo też metoda kognitywna nadaje się dobrze do modelowego opisu języka, ale dowieść nie jest w stanie niczego, jako że nie jest przydatna do empirycznego badania materiału językowego. Do tego celu bowiem potrzebne są precyzyjne narzędzia badawcze w postaci dokładnie rozróżnialnych kategorii i odpowiadających im dyskretnych terminów. Jako symboliczny wręcz można interpretować fakt, że autorzy kognitywnych prac o języku nie definiują terminów, lecz raczej opisują pojęcia i ilustrują je, rzadko wiadomo skąd pochodzącymi, przykładami.

Charakterystyczna dla prac kognitywnych dezynwoltura terminologiczna ${ }^{1}$, zgodna zresztą z zasadami tej teorii, nie szkodzi zasadniczo modelowym opisom języka czy rozmaitych jego podsystemów lub charakteryzujących je zjawisk. Problemy zaczynają się tam, gdzie w grę wchodzi badanie korpusu językowego², a zwłaszcza wtedy, gdy wyniki analiz mają mieć zastosowanie praktyczne. Taką dziedziną jest bez wątpienia glottodydaktyka. Cel badań prowadzonych dla jej potrzeb jest zdecydowanie utylitarny. Dotyczy to zarówno prób optymalizacji opisu systemu językowego, jak i poszukiwań zmierzających do ustalenia repertuaru leksykalno-frazeologicznego, którego aplikacja z jednej strony najskuteczniej podnosiłaby tempo i efektywność procesu glottodydaktycznego, $\mathrm{z}$ drugiej zaś przyczyniała się do usprawnienia samego procesu i metod nauczania. Ze względu na te właśnie szczegółowe badania precyzja stosowanego w tych badaniach aparatu pojęciowego i odpowiadającej mu terminologii ma znaczenie fundamentalne. Przesądza ona bowiem o tym, czy metodycy, praktycy i badacze, wymieniając między sobą ważne doświadczenia, które zmierzają do optymalizacji procesu nauczania języka jako obcego, będą zdani na to, żeby za każdym razem na nowo definiować stosowane przez siebie terminy ${ }^{3}$.

1 Przykładem może tu być chociażby znana i niezwykle popularna w Polsce książka George’a Lakoffa i Marka Johnsona o metaforze: Metafory w naszym życiu, Warszawa 1988 (tytuł oryginału: Metaphors we life by, Chicago 1980), gdzie definicje stosowanych terminów zastępowane są ich opisami, a podstawowe dla tego opracowania pojęcie metafory wcale nie zostało zdefiniowane. Nic więc dziwnego, że autor niemiecki Olaf Jäkel w swojej nawiązującej do ich założeń i również przetłumaczonej na język polski pracy Metafory w abstrakcyjnych domenach dyskursu (tytuł oryginału: Metaphern in abstrakten Diskurs-Domänen) dokonuje w części teoretycznej swoistej egzegezy teorii Lakoffa/ Johnsona, ujmując ją w „dziewięć głównych tez” wykoncypowanych z ich książki.

2 We wspomnianej pracy O. Jäkela (2003) deklarowana jest wprawdzie analiza korpusu, ale w opisie nie jest on pokazany.

3 Charakterystyczne jest tu, że autorka wyjątkowo klarownego pod względem terminologicznym i niezwykle konsekwentnego metodologicznie opisu materiałowych badań kompetencji leksykalnej osób uczących się języka polskiego (Seretny 2011) zapytana podczas swojego kolokwium habilitacyjnego o jedną z omawianych tu, a stosowaną przez nią w dyskursie opozycję terminologiczną nawiązującą do ujęcia Ewy Lipińskiej (Lipińska 2003) język ojczysty/pierwszy : język obcy/drugi przyznała otwarcie, że w obecnym stanie rzeczy każdy autor musi te pojęcia definiować dla swojej pracy indywidualnie. 
Wypada skonstatować, że w tej sytuacji stosowana w praktyce wielka różnorodność często synonimicznych wobec siebie wzajemnie terminów dotyczących podstawowych pojęć glottodydaktyki domaga się uściślenia i systematyzacji, gdyż obecny stan rzeczy utrudnia dialog w obrębie tej odmiany dyskursu. Chodzi o takie terminy jak z jednej strony język ojczysty/rodzimy/macierzysty/prymarny/pierwszy/wyjściowy/źródłowy (source), z drugiej zaś język obcy/sekundarny/drugi/docelowy (target), a także te dotyczące dwujęzyczności i wielojęzyczności jak bilingwizm, polilingwizm, dyglosja, poliglotyzm itp.

Tej potrzebie wydaje się wychodzić naprzeciw książka Ewy Lipińskiej (2003), której tytuł brzmi pod tym względem zdecydowanie obiecująco: Język ojczysty, język obcy, język drugi. Jeśli jednak ktoś oczekiwałby od tej pracy czegoś w rodzaju strukturalnej klasyfikacji terminów, sporządzonej bądź to na podstawie uzgodnienia różnorodnych definicji (co raczej nie wydaje się możliwe do wykonania), bądź na podstawie usystematyzowanych kryteriów, która by te pojęcia pozwoliła stosować w sposób dyskretny, to wypada otwarcie powiedzieć, że dozna rozczarowania. Autorka zestawia wprawdzie definicje języka ojczystego ze słowników i z prac różnych badaczy, a następnie formułuje własną, nie zajmuje jednak stanowiska wobec różnorodności i przypadkowości, tzn. braku systematyczności stosowanych w nich kryteriów i nie próbuje ich z sobą uzgodnić. W efekcie termin ten przedstawia się jako jeszcze bardziej nieostry niż przed rozpatrzeniem tych wszystkich ujęć.

Własna definicja autorki jest niejako syntezą wielu spośród wcześniej przytoczonych i na pierwszy rzut oka wydaje się całkowicie przekonująca, aczkolwiek, co charakterystyczne, nie ma ona klasycznej Arystotelesowskiej formy odpowiedzi na pytanie „co to jest x?”, lecz raczej przypomina opisowe formuły kognitywistów „czym jest x”:

Język ojczysty jest pierwszym poznawanym i „doświadczanym” (doznawanym) przez człowieka językiem, w którym się porozumiewa z otoczeniem. Ma on znaczący udział w poznawaniu świata i kształtowaniu struktury osobowości, sprawiając, że człowiek się z nim utożsamia, a w dorosłym życiu zazwyczaj w nim myśli, śni, liczy i modli się (Lipińska 2003: 15).

Dobry termin naukowy i dobra jego definicja odznaczają się tym, że obejmują odnośne pojęcie w jego pełnym zakresie znaczeniowym, nie pozostawiając wyjątków. Tymczasem definicja E. Lipińskiej warunku tego najwyraźniej nie spełnia. Przeciwnie, opisuje ona prototyp, a nie pełny zakres definiowanego pojęcia. Jak bowiem ma się ona do następującego przypadku:

Trzynastoletnia dziś dziewczynka, córka mieszanego polsko-niemieckiego małżeństwa, urodzona i od początku wychowywana w Niemczech do ukończenia mniej więcej trzeciego roku życia (kiedy to poszła do przedszkola) mówiła wyłącznie po polsku i osiągnęła w tym języku nadzwyczaj wysoką kompetencję, znacznie przekraczającą poziom przeciętnego polskiego trzylatka. Język ten przejęła od swojej polskiej opiekunki (niemówiącej po niemiecku). Również pracująca na pełnym etacie matka porozumiewała się wówczas z dzieckiem po polsku. Kiedy dziewczynka osiągnęła wiek przedszkolny, 
rodzice podziękowali opiekunce i odtąd przez większą część dnia przebywała w niemieckim środowisku językowym. Stopniowo również w kontaktach z matką język polski używany był coraz rzadziej, w miarę jak rosła kompetencja dziecka w niemieckim, a polska ulegała degradacji. Dziś osoba ta - uczennica drugiej klasy gimnazjum - mówi po polsku z wyraźnym akcentem i zabawnymi błędami gramatycznymi, po niemiecku zaś na wysokim poziomie jego rodowitego użytkownika ze środowiska inteligenckiego.

Nim przypadek ten poddany zostanie analizie pod kątem jego odniesienia do przytoczonej definicji, warto podkreślić, że nie jest on wymyślony na potrzeby niniejszej dyskusji, lecz całkowicie realny i zapewne nieodosobniony.

Zacznijmy od zagadki: który język jest językiem ojczystym tej osoby? Znacznej części definicji E. Lipińskiej odpowiadałby język polski. Rzecz w tym, że nie całej. Jest on, owszem, pierwszym poznanym przez tę dziewczynkę językiem, ale już następny warunek („w którym się porozumiewa z otoczeniem”) jest co najmniej wątpliwy. Po polsku porozumiewa się ona bowiem $\mathrm{z}$ otoczeniem jedynie kilka razy do roku przez krótki czas, kiedy z rodzicami odwiedza polskich dziadków. Natomiast na pewno nie myśli, nie śni i nie modli się po polsku. Żeby było jeszcze trudniej, osoba ta być może spełnia warunek utożsamiania się z językiem polskim. Tak w każdym razie można by interpretować reakcję dziewczynki na (zgodną z prawdą) uwagę niemieckiej babci, że jest pół Niemką, pół Polką. Odparła ona mianowicie (trudno ocenić, na ile serio) po niemiecku (sic!): „Nie, jestem całą Polką”.

Może zatem język niemiecki spełnia w opisywanym przypadku definiowane przez E. Lipińską kryteria języka ojczystego? Okazuje się, że też nie. Nie jest to przecież pierwszy (w każdym razie chronologicznie) język tej osoby, bo jest nim język polski, a i „znaczący udział w poznawaniu świata” jest wątpliwy, zważywszy na to, co mówi psychologia rozwojowa na temat okresu, w którym kształtują się podstawowe zręby osobowości, także te poznawcze.

Jeszcze bardziej sprawę komplikuje fakt, że E. Lipińska stosuje termin język ojczysty synonimicznie wobec terminu język pierwszy (ibid.: 41-42), co zresztą odzwierciedla sama definicja. Następny przykład jeszcze dosadniej obnaża niekonsekwencje takiego rozstrzygnięcia. Przypadek dotyczy (nieżyjącego już) mężczyzny, nawiasem mówiąc niemieckiego dziadka opisywanej dziewczynki:

Mężczyzna urodził się w okresie międzywojennym w Valparaiso. Jego ojciec był przedstawicielem dużej hamburskiej firmy armatorskiej. Stosownie do swojej pozycji rodzina wiodła w Chile styl życia dający się określić jako kolonialny: zamieszkiwała okazałą willę położoną w centrum dużej posiadłości ziemskiej i zatrudniała służbę, w tym opiekunki do dziecka. Chłopiec wychowywany był przez dwie hiszpańskojęzyczne kobiety: opiekunkę i guwernantkę. Matka początkowo nie zajmowała się wychowaniem syna. Pierwszym językiem, który przejął od swoich opiekunek i w którym kontaktował się z nimi, czyli ze swoim otoczeniem, był zatem hiszpański. Podobnie jak wiele lat potem w przypadku jego wnuczki sytuacja ta zmieniła się diametralnie, kiedy skończył trzy lata, a jego matka 
odkryła nie bez wzburzenia, że nie jest w stanie porozumieć się z własnym synem, jako że ten nie włada ojczystym językiem.

Czy niemiecki był istotnie jego ojczystym językiem, skoro nawet go nie znał? Sądzę, że tak, i w dalszej części postaram się pogląd ten uzasadnić.

W następstwie tego niespodziewanego odkrycia rodzice sprowadzili swojej latorośli opiekunkę i guwernantkę z Niemiec i tak ostatecznie zakończyła się przygoda chłopca z językiem hiszpańskim, zwłaszcza że wkrótce, w obliczu nieuchronnie zbliżającej się wojny, placówka niemieckiego armatora w Valparaiso została zlikwidowana i rodzina wróciła do kraju. W swoim dorosłym życiu mężczyzna ten nie znał hiszpańskiego zupełnie.

Co do tego, że hiszpański nie był jego językiem ojczystym, nie ma chyba najmniejszych wątpliwości. Ale zgodnie z definicją E. Lipińskiej - z wieloma innymi zresztą też - nie był nim również niemiecki, bo nie był „pierwszym poznawanym $\mathrm{i}$ »doświadczanym « (doznawanym) przez niego językiem, w którym się porozumiewał z otoczeniem". Porozumiewał się nim dopiero później, i to przez całą resztę życia, ale był to jego język drugi, a nie pierwszy. Identyfikował się z nim na pewno, ale czy tylko on miał „znaczący udział w kształtowaniu jego struktury osobowości”, a zwłaszcza „w poznawaniu świata”? Można w tej kwestii mieć co najmniej te same wątpliwości co w przypadku jego wnuczki.

A co zrobić, kiedy ktoś się identyfikuje z językiem (a w każdym razie taką składa deklarację), który zna słabo lub nie zna go wcale. Jest to dość częsta sytuacja w wypadku tzw. późnych wysiedleńców z Polski w Niemczech właśnie.

Wszelkie tego typu dylematy biorą się stąd, że większość definicji podstawowych terminów glottodydaktyki - nie tylko E. Lipińskiej - posługuje się eklektycznymi, enumeratywnie stosowanymi kryteriami, czego konsekwencją jest opisywanie prototypów zamiast rzeczywistego definiowania terminów.

Potrzebny jest zatem jakiś uporządkowany system kryteriów wraz z ustaleniem kolejności ich stosowania, który umożliwi klasyfikację podstawowych pojęć i dyskretne definiowanie odpowiadających im terminów.

Propozycja takiego systemu jest zasadniczym celem niniejszych rozważań. Wypada je rozpocząć od przedstawienia kryteriów, aby potem przejść do klasyfikacji i jej komentarza.

Kryteria mają charakter opozycji funkcjonalnych, którym odpowiadają wyniki ich zastosowania:

1. Kryterium - sposób akwizycji języka:

naturalny (przez naśladownictwo) - sztuczny (przez naukę)

Wynik: 
1.1. Kryterium - kolejność akwizycji

$$
1: 2: 3 \ldots \text { etc. }
$$

Wynik:

RODZIMY/OBCY: PIERWSZY $\rightarrow$ DRUGI $\rightarrow$ TRZECI...

2. Kryterium - opcja indywidualna.

Wynik:

$$
\text { OJCZYSTY } \leftrightarrow{ }^{4} \text { NIEOJCZYSTY }
$$

3. Kryterium - aktualność (aktywność) użycia: aktualnie używany : aktualnie nieużywany.

Wynik:

\section{AKTYWNY $\leftrightarrow$ PASYWNY}

3.1. Kryterium - zakres i częstość użycia.

Kryterium to z oczywistego powodu ma zastosowanie tylko do języka aktywnego. Wynik:

$$
\text { AKTYWNY: PRYMARNY } \leftrightarrow \text { SEKUNDARNY } \leftrightarrow \text { TERCJARNY... }
$$

Powstały w ten sposób dyskretny system podstawowych pojęć/terminów glottodydaktycznych wymaga oczywiście pewnego opisowego komentarza, aby mógł być w pełni zrozumiały. Przede wszystkim musi zostać wyjaśnione jego odniesienie do wspomnianych na początku różnorodnych terminów utrwalonych już w pewnej tradycji, a funkcjonujących jako określenia prototypów. Po drugie, komentarz ten będzie dotyczył relacji między poszczególnymi elementami (terminami) tego systemu.

Pierwsza z opozycji przeciwstawia język rodzimy językowi obcemu, z którym zazwyczaj oponowany bywa język ojczysty. Aby lepiej wyjaśnić tę różnicę, warto skonstruować coś w rodzaju opisowej definicji terminu język rodzimy:

Język rodzimy to ten język, który poznajemy w sposób naturalny wraz z poznawaniem otoczenia (świata). Odbywa się to zazwyczaj w środowisku rodzinnym, rzadziej w innym (np. sierociniec, rodzina zastępcza etc.), a osobą, od której przejmuje się tę kompetencję, jest zazwyczaj matka, rzadziej inny członek rodziny lub opiekun/ka.

Dwukrotnie użyty tu modulant $z a z w y c z a j$ jest oczywiście nieprzypadkowy i wskazuje na to, że całe drugie zdanie odnosi się do prototypu, a nie należy do definicji w ścisłym rozumieniu.

\footnotetext{
4 Symbol $\leftrightarrow$ oznacza zwrotność, czyli możliwość przechodzenia z jednej kategorii do drugiej.
} 
Jak widać, „definicja” ta częściowo, ale tylko częściowo, odpowiada przytoczonej na wstępie formule, za pomocą której E. Lipińska definiuje język ojczysty. Tak jak ona zresztą (lub bardzo podobnie) rozumie pojęcie języka ojczystego szereg innych autorów, na których się powołuje, m.in. Marinna Yaguello (1982), Tove Skuttnabb-Kangas (1981), M. Warchoł-Schlottmann (1994) $\mathrm{i}$ in.

Termin język ojczysty odnosi się w proponowanym tu systemie do całkiem innego pojęcia. Określa on język tego narodu, z którym identyfikuje się dana osoba, i to niezależnie od tego, czy deklaracja tej identyfikacji jest szczera, wynika z rzeczywistego poczucia przynależności do tradycji, kultury, racji stanu, systemu wartości, symboliki, często także religii oraz systemu stereotypów danej nacji i niezależnie od stopnia znajomości jej języka ${ }^{5}$. Zgodnie z takim rozumieniem język ojczysty - jak wszystko, co polega na wyborze - może się teoretycznie wielokrotnie zmieniać. Co więcej, możliwe są, wcale nie wyłącznie teoretycznie, przypadki całkowitej nieznajomości języka deklarowanego jako ojczysty, by przywołać tylko liczne przykłady tego zjawiska wśród polskich późnych wysiedleńców (Spätaussiedlerów) w Niemczech czy niektórych współczesnych repatriantów z Kazachstanu w Polsce.

Nie sposób jednak również postawić choćby przybliżonego znaku równości między zaproponowanym tu terminem język rodzimy a tym, co powszechnie - i wypada tu powiedzieć wprost: potocznie - nazywa się językiem ojczystym. Różnice bowiem są zbyt radykalne. Język rodzimy (a tym bardziej ojczysty) w proponowanym tu rzeczywiście terminologicznym rozumieniu na pewno nie jest językiem „dzieciństwa, którym mówi się najlepiej i którego się nigdy nie zapomina”, jak sądzi cytowana przez E. Lipińską (nota bene z krytycznym komentarzem) M. Yaguello (1982). Dowodzi tego jednoznacznie przytoczony tu przykład Niemca urodzonego w Valparaiso. Nie można również bez wątpienia powiedzieć, że jest to język, „który dziecko poznaje jako pierwszy, z którym dana osoba się utożsamia”, jak chce T. Skuttnabb-Kangas (1981, cyt. za: Lipińska 2003: 14). Opisywany we wspomnianym przykładzie mężczyzna poznał hiszpański jako pierwszy. Byłby to zatem w proponowanym tu rozumieniu jego język rodzimy, w dodatku pierwszy (rodzimy), ale na pewno nie ojczysty (w żadnym z wchodzących w grę sensów), bo się z nim w dorosłym życiu bynajmniej nie utożsamiał (to, że go wtedy już nawet nie znał, ma w tym wypadku drugorzędnie znaczenie).

Liczne, a w Polsce coraz liczniejsze ostatnio, przykłady dzieci z mieszanych małżeństw pokazują ponadto, że możliwych jest kilka języków rodzimych, nawet więcej niż dwa, jak na przykład w przypadku dziecka mieszanego polsko-angielskiego małżeństwa zamieszkałego w Szwajcarii. Przyswajanie tych (rodzimych) języków może być

5 Wcale nierzadkie przypadki deklarowania polskiej narodowości oraz języka polskiego jako ojczystego pomimo słabej jego znajomości przez uczniów szkoły polskiej we Lwowie, a także przez studentów Uniwersytetu Lwowskiego uczących się języka polskiego na poziomie podstawowym (sic!) opisują w swoich, przygotowanych pod moim kierunkiem, pracach magisterskich Agnieszka Kulak (2010) i Urszula Litkowska (2009). Na podobne zjawisko wśród uczniów ukraińskojęzycznego gimnazjum w Przemyślu wskazuje Katarzyna Dzierżawin (2009). 
sekwencyjne albo symultaniczne (lub raczej quasi-symultaniczne). W przywołanym tu przykładzie dziecko przyswajało sobie równocześnie języki polski i angielski, a następnie (od momentu pójścia do przedszkola) także niemiecki. Teoretycznie możliwe są konstelacje obejmujące jeszcze większą liczbę języków. Który (które?) z nich stanie (staną?) się językiem (językami) ojczystym/i, to zależy od wyboru dokonanego wtedy, kiedy dziecko do niego dorośnie. Ten wybór może się zmieniać w ciągu życia jednostki. Dlatego język ojczysty w proponowanym tu rozumieniu może się zmieniać: dotąd nieojczysty stawać się ojczystym i odwrotnie. Zwrotność tej relacji zaznaczono tu symbolem $\leftrightarrow$. Możliwe jest również, że ktoś uzna za swój język ojczysty któryś z języków obcych, w skrajnym przypadku nawet taki, którego nigdy się nie nauczy ${ }^{6}$. Nierzadkie też są przypadki osób deklarujących więcej niż jedną narodowość i stosownie do tego dwa (rzadziej chyba więcej) języki ojczyste ${ }^{7}$.

Również użycie terminu język obcy wymaga tu uzupełniającego komentarza, jako że jego znaczenie też odbiega nieco od tego, w którym potocznie bywa używany, przeważnie w opozycji do terminu język ojczysty i mniej więcej synonimicznie w stosunku do terminu język docelowy (target language) oponowanego z określeniem język źródłowy względnie wyjściowy (source language). Zasadniczym znaczeniem, w jakim stosowany jest tutaj termin język obcy jest 'język przyswajany w sposób sztuczny, to znaczy poprzez intencjonalny wysiłek intelektualny ukierunkowany na jego poznanie, czyli naukę’ w opozycji do języka rodzimego, przyswajanego w sposób naturalny czyli przez naśladownictwo. Tylko implicite tak rozumiany termin ten obejmuje również pojęcie języka nieznanego, który ma być dopiero poznawany lub jest poznawany (target language). Warto w tym miejscu zwrócić uwagę, że powszechnie stosowany zwrot znać języki obce czy jego zbiurokratyzowany wariant w postaci wyrażenia znajomość języków obcych nie są oksymoronami tylko w zaproponowanym tutaj znaczeniu, co słuszność tego rozwiązania zdaje się wyraźnie potwierdzać.

Terminy język pierwszy, drugi, trzeci etc. są w proponowanym systemie używane wyłącznie dla określenia chronologicznej kolejności ich przyswajania - drogą naturalną w przypadku języka rodzimego lub poprzez naukę w przypadku języków obcych. Terminy te będą zatem występowały zawsze w połączeniu z informacją, jakiego języka dotyczy określenie kolejności, o ile nie wynika ona jednoznacznie z kontekstu: pierwszy rodzimy, drugi rodzimy... etc. lub pierwszy obcy, drugi obcy... etc.

Kryterium aktualności użycia jest podstawą opozycji terminów: język aktywny-język pasywny. Pierwszy z nich oznacza język będący aktualnie w aktywnym użyciu, niezależnie od tego, czy jest to język rodzimy (któryś z rodzimych) czy obcy (któryś z obcych). Język pasywny natomiast to taki, który dana osoba zna, ale go aktualnie nie używa. Jeśli

6 Takie osoby można spotkać w Niemczech wśród późnych wysiedleńców z Polski. Są to przeważnie osoby starsze, które w późnym wieku opuściły nasz kraj. Ich wybór narodowy, a więc i językowy, ma charakter formalny (udokumentowany) i stanowi warunek przyznania im statusu Spätaussiedlera.

7 Przypadek taki opisuje między innymi Barbara Godłowska w swojej pracy magisterskiej (2010). 
stan taki trwa dłuższy czas, wtedy język ten ulega stopniowo degradacji aż do całkowitego zaniku. Ponieważ jednak pojęcie aktywności nie jest kategorią absolutną (pasywność można by ewentualnie za taką uznać), lecz stopniowalną, potrzebne są hiponimiczne terminy uwzględniające tę gradację: to znaczy określające zakres i częstość użycia czyli jego intensywność. Mogłaby się do tego nadawać sekwencja terminów aktywny pierwszy, drugi, trzeci... etc., gdyby nie to, że wystąpiła ona już w funkcji określania kolejności akwizycji (i to w dwóch wariantach: w odniesieniu do języków rodzimych i obcych). W tej sytuacji lepsze wydają się terminy język prymarny, sekundarny, tercjarny... etc., zwłaszcza że nie wymagają dodawania atrybutu „aktywny”.

Proponowany tu system terminów stanowi swego rodzaju klasyfikację języków z punktu widzenia glottodydaktyki. Syntetyczne spojrzenie na nią ułatwić może następujący diagram:
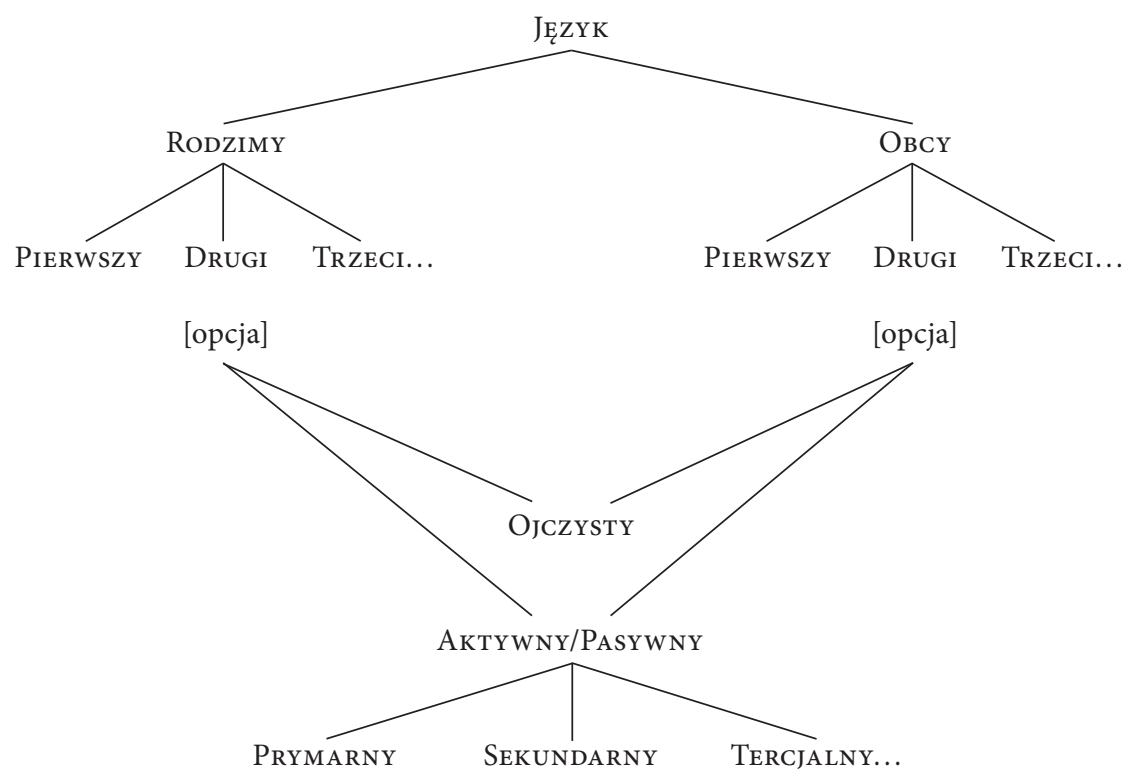

Z przedstawienia tego wynika, że tylko opozycja język rodzimy : język obcy (wraz z podporządkowaną jej specyfikacją chronologiczną) ma charakter naturalny. To zaś, który język stanie się językiem ojczystym, aktywnym bądź pasywnym, jest kwestią wyboru. Domenę wyboru stanowią zarówno języki rodzime, jak i obce, choć ten drugi przypadek jest o wiele rzadszy. Językiem ojczystym jest zazwyczaj (prototypowo) któryś z języków aktywnych, najczęściej (prototypowo) rodzimy, ale może to być także język pasywny. Sienkiewiczowski Latarnik jest skrajnym przykładem takiej sytuacji.

Proponowany system terminów (glottodydaktyczna klasyfikacja języków) nie zawiera opozycji język wyjściowy/źródłowy (source) : język docelowy (target). Nie wynika 
to jednakże z niedopatrzenia, lecz jest spowodowane nieorganicznym charakterem tej opozycji w stosunku do przedstawionej klasyfikacji. Ta bowiem dokonywana jest $\mathbf{z}$ punktu widzenia glottodydaktyki, a więc z perspektywy zewnętrznej (egzocentrycznej, jeśli się komuś ta nazwa bardziej spodoba), zaś opozycja source : target postrzegana jest $\mathrm{w}$ obrębie procesu glottodydaktycznego, a więc $\mathrm{z}$ perspektywy wewnętrznej (endocentrycznej).

Uporządkowania i uściślenia wymagają również terminy dotyczące dwujęzyczności i wielojęzyczności, takie jak bilingwizm, dyglosja, polilingwizm, multilingwizm, poliglotyzm. Abstrahując nawet od tak niejasnych pojęć i niekonsekwentnie stosowanych terminów jak dyglosja, który czasem pojmowany jest jako synonim bilingwizmu, a i sam w sobie jest mocno nieprecyzyjny (zob. Lipińska 2003: 128-131), warto się przynajmniej zatroszczyć o uściślenie pojęcia bilingwizmu (zakładając, że termin ten jest synonimem dwujęzyczności), a przede wszystkim o ustalenie relacji między terminami: polilingwizm, multilingwizm i poliglotyzm. Proponowana tu glottodydaktyczna klasyfikacja języków zdaje się dostarczać do tego celu dobrej podstawy.

E. Lipińska (ibid.) przytacza liczne definicje bilingwizmu, wprowadzając najpierw podział na bilingwizm indywidualny i społeczny. Charakterystyczne, że w definicjach bilingwizmu społecznego wiąże się to z zjawisko z grupą społeczną lub z terytorium, na którym ono występuje, natomiast ci, którzy definiują bilingwizm indywidualny, skupiają się na kryterium kompetencji lub na kryterium użycia.

Charakterystyczna dla tego pierwszego typu definicji jest przytaczana przez autorkę formuła J.P. Oestereichera, w której jest wręcz mowa o „kompletnym opanowaniu dwóch języków bez interferencji” (cyt. za: Lipińska 2003: 103). Wypada tu zwrócić uwagę na nieostrość sformułowania „kompletne opanowanie” i wyrazić wątpliwość, czy brak interferencji jest pewnym, łatwym do zastosowania i jedynym kryterium owej „kompletności”. Nic dziwnego, że w tej sytuacji inni autorzy (których też cytuje E. Lipińska) są przeciwnego zdania: skłonni są uznać za osobę bilingwalną tego, kto tylko trochę zna drugi język.

Definicje posługujące się kryterium funkcjonalnym zwracają natomiast uwagę na używanie dwóch języków „na przemian” (Uriel Weinreich cytowany za W. Woźniakowskim), ,,alternatywnie” (Wiliam Mackey cyt. za T. Skuttnabb-Kangas, 1981), ,,Z przełączaniem kodów” (E. Oscar cytowany j.w.). Warunek ten dobrze charakteryzuje sposób, w jaki przejawia się bilingwizm, ale nie pomaga w szukaniu odpowiedzi na postawione przez E. Lipińską pytanie: dwujęzyczność czy znajomość dwóch języków (tak autorka zatytułowała jeden z podrozdziałów swojej książki)? Nie przyda się też do tych poszukiwań kryterium kompetencji. Zapewne dlatego rezygnuje z niego Ida Kurcz, definiując dwujęzyczność:

Przez dwujęzyczność (wielojęzyczność) będziemy rozumieć fakt posługiwania się przez daną osobę dwoma (lub więcej niż dwoma) językami, przy czym nie określa się bliżej stopnia znajomości tych języków (Kurcz 1992: 80). 
Lipińska jednak, odczuwając wyraźnie potrzebę rozróżnienia między bilingwizmem (dwujęzycznością) a znajomością dwóch języków, postanowiła zaufać kryterium kompetencji, w efekcie czego powstały takie oto dwie różnicujące definicje (autorka ujmuje je w ramki):

Znajomość języka obcego - to kompetencja w języku obcym nieadekwatna do wieku i stanu społecznego danej osoby, znajomość sprawności, używanie języka obcego tylko w pewnych sytuacjach (Lipińska 2003: 114).

Gdyby taką definicję potraktować całkiem dosłownie, to wypadałoby dojść do wniosku, że znajomością języka obcego odznacza się tylko ten, kto ów język zna słabo, w stopniu „nieadekwatnym do wieku i stanu społecznego”, opanował „tylko niektóre sprawności” i potrafi go używać „tylko w niektórych sytuacjach”. Można z niej także wnioskować dalej, że ten, kto obcy język opanował dobrze czy, jak chce wspomniany wyżej J.P. Oestereicher, „kompletnie”, jest osobą dwujęzyczną. Definicja dwujęzyczności według E. Lipińskiej zdaje się to potwierdzać.

Dwujęzyczność - to opanowanie dwu języków w takim stopniu, jak społecznie ekwiwalentni jednojęzyczni ich nosiciele, czyli ambilingwizm. Polega na umiejętności posługiwania się wszystkimi sprawnościami w języku ojczystym i drugim oraz na częstym używaniu obu języków w różnych sytuacjach i z różnymi uczestnikami aktu komunikacji (Lipińska 2003: 115).

Preferowane jest tu wyraźnie kryterium kompetencji, którego zawodność dla definiowania bilingwizmu dostrzegają inni badacze, by wspomnieć choćby opinię I. Kurcz, która za dwujęzyczność (wielojęzyczność) uznaje po prostu „fakt posługiwania się przez daną osobę dwoma (lub więcej niż dwoma) językami, przy czym nie określa się bliżej stopnia znajomości tych języków" (1992: 180)

Nazwa dwujęzyczność zyskuje jeszcze jeden synonim (oprócz bilingwizm) w postaci przejętego od Franciszka Gruczy (1981) terminu ambilingwizm, przy czym jednak autorka zaznacza (w przypisie, s. 115), że jest jednak między nimi pewna różnica: "Ambilingwizm nie zakłada pełnego opanowania obu języków" (sic!). Chciałoby się więc w tym miejscu zapytać: co w takim razie uzasadnia użycie spójnika (włącznego) czyli w tej definicji? Tę drobną niekonsekwencję można by bez uszczerbku dla dyskutowanej kwestii zlekceważyć, gdyby na niej kończyły się wątpliwości.

Tymczasem użyte tu sformułowania pełne są niejasności. Co bowiem znaczy na przykład „społecznie ekwiwalentni ich nosiciele”, skoro różnice kompetencji językowej w obrębie tej samej klasy społecznej mogą być ogromne? To samo dotyczy

8 Autorka wraca jednak do nieszczęsnego kryterium stopnia znajomości języka, wyróżniając dwujęzyczność (wielojęzyczność) zrównoważoną (kiedy ktoś zna dwa języki lub więcej w takim samym stopniu) i pełną (kiedy ktoś ma pełną kompetencję w obu/kilku językach) (ibid.: 180). Jakie kryterium, takie wyniki. Jak ocenić, czy ktoś zna dwa, a tym bardziej kilka języków, w równym stopniu? Albo czy jego kompetencja jest w każdym z nich pełna czy niepełna? 
sformułowania „posługiwanie się wszystkimi sprawnościami”, bo co w takim razie na przykład z jednojęzycznymi analfabetami? Czy są oni „społecznymi ekwiwalentami” analfabetów dwujęzycznych? A już przymiotnik częsty w odniesieniu do rozmaitych sytuacji użycia języka jest typowym atrybutem ocennym. Na podstawie takich „kryteriów" trudno więc oczekiwać precyzyjnej definicji, która by pozwoliła w praktyce odróżnić osobę bilingwalną od takiej, która zna dwa języki (lub więcej). Kryterium kompetencji to inaczej kryterium stopnia znajomości (języka) i ten jego ocenny, arbitralny charakter („stopień") powoduje, że prowadzi ono w ślepy zaułek we wszystkich definicjach (cytowanych przez E. Lipińską i niecytowanych).

Wydaje się, że stosownym kryterium, pozwalającym jednoznacznie zdefiniować bilingwizm i dyskretnie odróżnić osobę dwujęzyczną od znającej dwa języki obce, a także osobę wielojęzyczną (polilingwalną) od poligloty, który zna wiele języków obcych, jest to, które w zaproponowanej glottodydaktycznej klasyfikacji języków stanowi podstawę opozycji język rodzimy : język obcy, czyli sposób akwizycji.

Wynik zastosowania tego kryterium jest prosty i klarowny: kto pozyskał więcej niż jeden język w sposób naturalny, przez naśladownictwo, ten jest bilingwistą resp. polilingwistą, czyli osobą władającą dwoma resp. wieloma językami rodzimymi, kto zaś w sposób sztuczny, poprzez naukę, opanował kilka języków obcych, ten jest poliglotą. Brak tu stosownego terminu dla nazwania sytuacji, kiedy ktoś oprócz języka rodzimego zna jeden tylko język obcy (którego się nauczył). Nadawałaby się do tego nazwa dyglosja, gdyby nie fakt, że taki termin już istnieje i ma już pewną tradycję, chociaż - jak pokazuje E. Lipińska - sam w sobie też jest kontrowersyjny ${ }^{10}$.

Przedstawiona tu propozycja uporządkowania podstawowych terminów glottodydaktycznych nie aspiruje oczywiście do rangi jedynej możliwej, zwłaszcza że jest prawdopodobnie pierwszą taką próbą. Ma natomiast w zamyśle autora być alternatywą dla panującego obecnie powszechnie chaosu terminologicznego. Spełni ona swoją funkcję zarówno w przypadku, gdyby udało się jej zdobyć uznanie środowiska glottodydaktycznego, jak i wówczas, kiedy da impuls do opracowania innych, lepszych, to znaczy prostszych i bardziej precyzyjnych propozycji w tym zakresie.

Na koniec należy się odpowiedź na drugą część pytania zawartego w tytule: po co podejmować takie zadanie? Po pierwsze po to, żeby piszącym na te tematy autorom rozpraw i wymieniających się doświadczeniami praktykom glottodydaktyki oszczędzić definiowania wciąż na nowo używanych terminów, po drugie, żeby wiedzieć, kto poliglota, a kto dwu/wielojęzyczny. Jest to nota bene pochodna różnicy między kulturą a naturą, na której temat publiczne dyskusje od czasu do czasu niemal dosłownie wybuchają. Pewnie i tu przydałoby się jakieś dyskretne kryterium.

9 Większość praktycznych opisów środowisk bilingwalnych dotyczy takich właśnie przypadków, por. np. Michalewska 1991.

10 Jedni odnoszą go do odmian tego samego języka etnicznego, inni do odrębnych języków, a jeszcze inni do jednego i drugiego (por. Lipińska 2003). 


\section{Literatura}

DzIERżAwIN K., 2009, Bilingwizm polsko-ukraiński. Badania wśród ukraińskiej młodzieży uczącej się w Przemyślu, „Kijowskie Studia Polonistyczne”, Kijów.

GodŁowsKa B., 2010, Tożsamość kulturowa a kompetencja językowa (bilingwizm polsko-litewski), Kraków (praca magisterska, mszps).

Grucza F., 1981, Glottodydaktyczne implikacje bilingwizmu, [w:] F. Grucza (red.), Bilingwizm a glottodydaktyka. Materiały z V sympozjum zorganizowanego przez Instytut Lingwistyki Stosowanej UW, Białowieża, 26-28 maja 1977, Warszawa.

JäKel O., 2003, Metafory w abstrakcyjnych domenach dyskursu, Kraków.

KulaK A., 2010, Dwujęzyczność polsko-ukraińska na przykładzie uczniów szkoły polskiej we Lwowie, Kraków (praca magisterska, mszps).

KurCz I., 1992, Język a psychologia, Warszawa.

LAKOFF G., JoHnson M., 1988, Metafory w naszym życiu, Warszawa.

LiPIŃsKa E., 2003, Język ojczysty, język obcy, język drugi, Kraków.

Litкowska U., 2009, Analiza błędów w wypracowaniach pisemnych jako źródło informacji zwrotnej w glottodydaktyce, Kraków (praca magisterska, mszps).

Michalewska M.T., 1991, Polszczyzna osób bilingwalnych w Zagłębiu Ruhry w sytuacji oficjalnej, Kraków.

SERETNY A., 2011, Kompetencja leksykalna uczących się języka polskiego jako obcego w świetle badań ilościowych, Kraków.

SkuttnabB-Kangas T., 1981, Bilingualism or not: The Education of Minorities, London.

WarchoŁ-Schlottmann M., 1994, Próba opisu kompetencji językowej niemieckiej i polskiej u Polaków w Niemczech - studium lingwistyczne, Kraków.

Yaguello M., 1982, La langue maternelle, [w:] M. Yaguello, Catalogue des ideés reçues sur la langue, Paris.

\section{How to put order into the terminological chaos in language pedagogy and what should one want to do this for? \\ Summary}

The terminology used in language pedagogy does not constitute a coherent system because it is not based on definitions of terms but rather on descriptions of prototypes and illustrating them with examples. As a result, different terms overlap. This is disadvantageous for discourse in language pedagogy, because it enforces terms to be redefined anew in every statement.

The current article proposes a way to order and systematize terminology referring to, on the one hand, languages as viewed from the perspective of language pedagogy, and on the other, to the phenomenon of bi- and multilingualism.

Based on five systematically employed criteria, a discrete set of terms has been obtained which reflect the language pedagogical (i.e. prepared from the point of view of language pedagogy) classification of languages.

The first criterion allows also a bi- or multilingual person to be unambiguously distinguished from a polyglot. The first term describes someone who has acquired two or more native languages, while the second a person who has learned several or many foreign languages. The criteria of competence or of circumstances of use, which have so far been in common use, do not allow for such a clear distinction. 